\title{
CLIMATE CHANGE AND ITS EFFECT ON LAND USE CHANGE IN THE CENTRAL RIFT VALLEY OF ETHIOPIA
}

\author{
Bekele, B. ${ }^{1,2}-\mathrm{WU}, \mathrm{W} .{ }^{1,3^{*}}-$ YiRSAW, E. ${ }^{4}$ - Negussie, W. ${ }^{1,2}-$ Alemayehu, A. ${ }^{1,2}$ \\ ${ }^{1}$ College of Land Management, Nanjing Agricultural University, Nanjing 210095, China \\ (e-mail: belewbekele@yahoo.com (B.B.);wube14@yahoo.com (N.W.); \\ asferaalem2011@yahoo.com (A.A))
}

${ }^{2}$ Department of Natural Resources Management, Assosa ATVET College, Assosa 242, Ethiopia

${ }^{3}$ National and Joint Local Engineering, Research Center for Rural Land Resources Use and Consolidation, Nanjing 210095, China

${ }^{4}$ Department of Natural Resources Management, Dilla University, Dilla 419, Ethiopia

(e-mail: eshetu.yirsaw@yahoo.com)

${ }^{*}$ Corresponding author

e-mail:ww@njau.edu.cn; phone: +86-137-7065-1675

(Received $11^{\text {th }}$ Mar 2019; accepted $1^{\text {st }}$ May 2019)

\begin{abstract}
Climate change and variability have been one of the challenges to socioeconomic and environmental sustainability in the twenty-first century. Meteorological analyses of historical drought occurrences are common in East Africa, but studies devoted to its effect on land use change are yet limited. This paper aimed to assess the long-term rainfall and temperature variability and its effects on farmers' land use change in the Central Rift Valley of Ethiopia over the past 30-36 years using a combination of meteorological and socioeconomic data. Results show that the overall coefficient of variation for rainfall was more than $35 \%$ for rainy seasons. Out of the 36 years, total rainfall of the rainy season showed negative anomalies for about half of these years. Summer season rainfall started after the average time of onset for about $42 \%$ of the database years, and it ceased ahead of the average time of the stop for about $56 \%$ of these years. As a result of such rainfall shortage and variability, about $82 \%$ of the drought-vulnerable farmers had already changed their land use from pastoralist/agropastoralist to mixed farming while $10 \%$ have a wish to shift to other land use options in the future. Hence, future policies need to consider strategies that strengthen the adaptation capacity of farmers to climate change in East Africa.
\end{abstract}

Keywords: 'Belg', coefficient of variation, drought, 'Kirmet', rainfall, temperature

\section{Introduction}

Climate change and variability have been one of the challenges to socioeconomic and environmental sustainability in the twenty-first century (UNFCCC, 2018). The change in climate is accelerating faster than the global effort to address it. Studies show that the atmospheric concentration of greenhouse gases (GHG) has increased more in recent decades than at any time in the past of human history (IPCC, 2007, 2014). This increase in GHGs, in turn, lead to global warming with its related catastrophes to life on Earth like extreme storms, droughts, fires, floods, ice melting, and rising in sea levels (IPCC, 2007, 2014; Eckstein et al., 2017). According to Maharjan and Joshi (2013), global average surface temperature and atmospheric concentration of $\mathrm{CO}_{2}$ have been rising at an increasing rate, especially since the 1900s. With current mitigation efforts, future projections also indicate a continual increase for GHGs and temperature trends (Ravindranath and Sathaye, 2002; IPCC, 2014). Such threats, in general, made the 
climate change issue, one of the top agendas of discussion among the global research community and political leaders in recent decades.

Climate change could affect the ecosystem and human well-being in several ways. For instance, climate change could affect regional agricultural production yield, food price and food security (Sivakumar, 1992; Ravindranath and Sathaye, 2002; Barron et al., 2003), and it could affect human, plant, and animal health through its direct and indirect impact on physiology (Maharjan and Joshi, 2013; Pedrono et al., 2016). Climate change also affects ecosystem services and functioning by deteriorating biological, hydrological and atmospheric systems (Ravindranath and Sathaye, 2002; Pedrono et al., 2016). Additionally, climate change can force vulnerable communities to wholly or partially change their land use systems and livelihoods (Biazin and Sterk, 2013), and hence affect household income and social security. Furthermore, climate change can increase the costs incurred by mitigation and adaptation to overcome its impacts (Maharjan and Joshi, 2013).

The impact of climate change is more severe in developing nations where the income of the majority of the population directly depends on climate-sensitive economic sectors (e.g., agriculture) (UNFCCC, 2007; Torquebiau et al., 2016), as agriculture is not only contributing to climate change through GHG emissions, but is also most affected by it. According to Ravindranath and Sathaye (2002) and UNFCCC (2007), the region of Sub-Saharan Africa, south and east Asia, and the tropics of Latin America are particularly vulnerable to climate change. Studies show that the Sahel region in West Africa is well known for its severe environmental problems of drought and desertification over a long period of its history (Sivakumar, 1992; Agnew and Chappell, 1999). Similarly, the East African region is known for its recurrent severe drought in the last several decades (Barron et al., 2003). Beside such a high degree of vulnerability in developing countries, the adaptive capacity to overcome climate change impact is low due to financial, institutional, technological, and political constraints. For instance, Collier et al. (2008) and Gemeda and Sima (2015), pointed out that the impact of climate change on Africa is probably severe because of high agricultural dependency and limited capacity to adapt.

Besides primary socioeconomic drivers, climate change vulnerability is another crucial factor affecting agricultural land use (Dale, 1997; Reid et al., 2000; Biazin and Sterk, 2013; Ahmed et al., 2016). For example, Ahmed et al. (2016), found that the expansion in agricultural land use was mainly due to climate change in West Africa. These authors pointed out that unless agriculture is intensified, the climate-induced decline in crop yield coupled with a future increase in food demand will continue to increase agricultural area at the expense of forest and grassland loss in West Africa. The other study elsewhere showed that in addition to climatological deviations, drought vulnerability is also affected by the type of land use and social traditions of life. For instance, according to Biazin and Sterk (2013), the pastoral way of life was found to be more vulnerable to severe drought than mixed farming land use system. Similarly, a rain-fed cultivation is likely to be more susceptible to climate change than irrigated cropping, and a mono-cropping system is expected to be more vulnerable than a mixed cropping system, for example, agroforestry. Hence, according to Dale (1997) as a means of adaptation to climate change, vulnerable farmers usually try to modify/shift from a land use system that is more vulnerable to a land use system that is less vulnerable. 
Climate change and variability can be evaluated using different climatic indices and datasets. Studies show that temperature and precipitation are the two most frequently used climatic variables for evaluating climate variability and its impacts (Maharjan and Joshi, 2013). This is because there is an advantage of data availability in using, for example, rainfall, to investigate drought occurrence instead of using other variables, for example, river flow, which is increasingly managed by human action (Agnew and Chappell, 1999). Mean, median, a coefficient of variation, standard deviation, and the probability of dry spells are commonly used statistical parameters to describe both rainfall and temperature variability (Stern et al., 2006). In addition, the Standardized Precipitation Index is usually employed to evaluate long-term rainfall deviation from the usual norm (Agnew and Chappell, 1999; Agnew, 2000; Bewket and Conway, 2007; WMO, 2012; Viste et al., 2013). Irrespective of the type of indices used for climate change analysis, most climatologists advise using precipitation and temperature data of the long-term period and data from the wider gaging stations for better accuracy of results (Ali and Lebel, 2009).

Ethiopia is one of the countries in the Horn of East Africa hit by frequent drought over the last century. This was confirmed by various local and national level studies conducted in the country (Bewket and Conway, 2007; Cheung et al., 2008; Viste et al., 2013). For instance, Seleshi and Zanke (2004) found a significant decline in the annual and summer season total rainfalls since 1982 for the eastern, southern, and southwestern parts of the country. Cheung et al. (2008) in their long-term (1960-2002) rainfall data series analysis, found a significant decline in summer rainfall in southwestern and central parts of Ethiopia and pointed rainfall trends as one of the most important factors determining different socioeconomic constraints such as food insecurity in the country. The study by Rosell (2011) for three decades (1987-2007), indicated a decline in rainfall and an increase in temperature for the spring season in the central highlands of Ethiopia. Besides, Viste et al. (2013) found that the years 1972-1975, 1980-1982, 1984, 1987, 1990-1992, 1999-2000, 2002-2003, and 2008-2011 were the periods of severe drought episodes in Ethiopia. Furthermore, the recent 3-5 decades temperature and rainfall data analysis by Fazzini et al. (2015) reported a markedly increasing and decreasing trend for minimum temperature and annual spring season rainfall respectively in the country. However, there are studies reported the absence of significant variation, particularly in terms of total annual rainfall, as opposed to the farmers' usual perception of total rainfall shortage in most parts of Ethiopia (Conway, 2000; Conway et al., 2004; Seleshi and Zanke, 2004; Kassie et al., 2013; Adimassu et al., 2014). The main reason for these divergent results in the trend analysis of the annual rainfall of the country is the difference in base periods used for analysis (Agnew and Chappell, 1999; Bewket and Conway, 2007). In general, Ethiopia as a country whose economy is mainly dependent on rain-fed agriculture, the trend of seasonal rainfall is an important factor determining the socioeconomic functioning, particularly food production potential of the country (Bewket and Conway, 2007; Mideksa, 2010; Fazzini et al., 2015; Fekadu, 2015).

The Central Rift Valley (CRV) of Ethiopia is a semi-arid region known for its persisted shortage of agricultural rainfall in the country. Previous studies indicated the presence of drought vulnerability due to seasonal rainfall variability in the area (Biazin and Sterk, 2013; Kassie et al., 2013; Gizachew and Shimelis, 2014; Getachew and Tesfaye, 2015). However, works of literature devoted to climate variability and its impacts on farmers' land use change are currently limited in Ethiopia. Additionally, in a 
diversified agroclimatic condition, like in Ethiopia, a local level analysis is quite important as meteorological results usually vary for regional, local and even individual gaging stations. Furthermore, for climate change-prone and rain-fed dependent agricultural area, like in CRV, up-to-date climatic trend information is quite crucial to practice climate-responsive agriculture and to minimize climate-related production risks. Hence, this study is intended to 1) assess long-term rainfall and temperature change and variability over the last 30-36 years and 2) assess the possible effects of this climatic variability on land use/livelihood change by vulnerable farmers. It is believed that the output of such analysis partly helps the stakeholders to have an informed decision for future policy direction and better management strategies.

\section{Materials and Methods}

\section{The study area}

The CRV is located about $160 \mathrm{~km}$ south of the capital city Addis Ababa, Ethiopia. Geographically, the study site is situated within $7^{\circ} 10^{\prime}-8^{\circ} 30^{\prime}$ north latitude and $38^{\circ} 15^{\prime}-39^{\circ} 25^{\prime}$ east longitude (Figure). It is part of the Main Ethiopian Rift system which is characterized by an area of depression zone with steep marginal faults along its eastern and western edges. It is found within the current administrative boundary of Oromia and Southern Nations, Nationalities and Peoples (SNNP) Regional States.

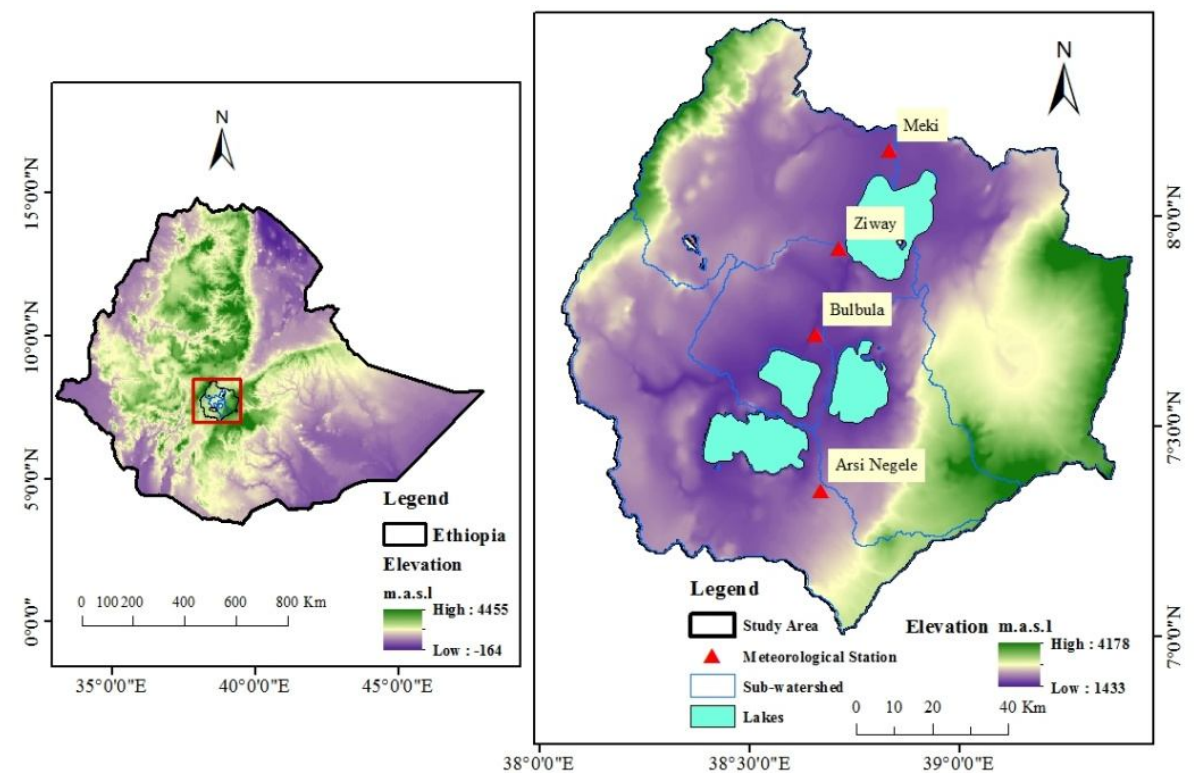

Figure 1. The study site location map with agroclimatic zones

Due to the unique topographical and geological feature of the region, the climate of CRV is known to vary markedly with altitude and season (Jansen et al., 2007). It is semi-arid in the areas along rift floor, and humid to sub-humid in the highland zone. As shown in Figure, the study area receives a bimodal annual rainfall distribution pattern in which the small light rain occurs during Belg (spring) season (February to May), and this is followed by the main rain that occurs during Kirmet (summer) season (June to September). The peak rainy months are July and August. The dry season (Bega) 
(winter), on the other hand, extends from October to January. According to data from the National Meteorological Agency (NMA), the mean annual rainfall is about $740 \mathrm{~mm}$, and the mean minimum and maximum annual temperatures are $13^{\circ} \mathrm{C}$ and $27^{\circ} \mathrm{C}$, respectively. In general, studies show that rain-fed agriculture in CRV is constrained by the highly erratic nature of rainfall in the region in recent decades (Jansen et al., 2007).

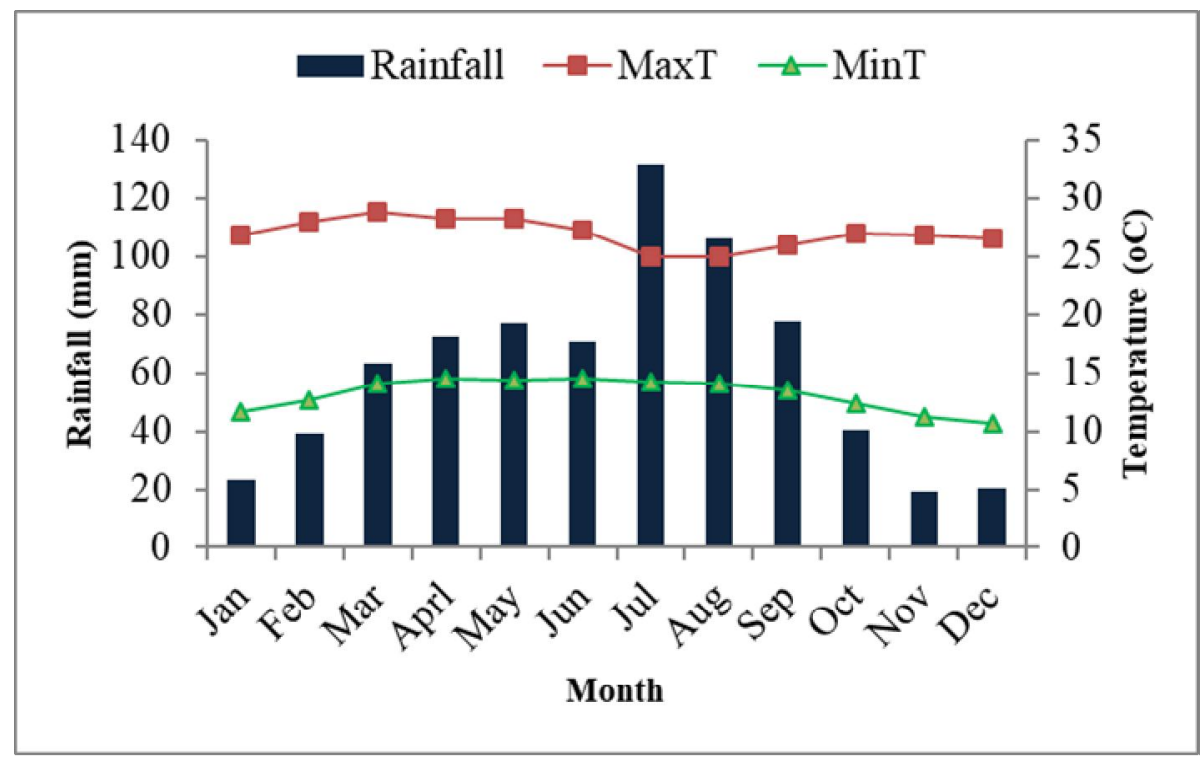

Figure 2. Average monthly rainfall and temperature at $C R V$ : MaxT = maximum temperature, MinT = minimum temperature: Data from NMA

The common land use/cover types of the study area include agricultural land, scattered acacia woodland, water body, shrub/bushland, grass/grazing land, marshy/swampy land, and bare land as described in Bekele et al. (2018a). The dominant and peculiar vegetation type in the region is acacia woodland. As a result of continual deforestation for agricultural land expansion, charcoal making, and fuelwood extraction, the acacia woodland of the region has been highly decreased from time to time over the last half century (Garedew et al., 2009; Biazin and Sterk, 2013; Temesgen et al., 2013; Ariti et al., 2015). Four of the principal Ethiopian lakes namely: Abijata, Shalla, Ziway, and Langano are found within the catchment of CRV basin. The first two lakes are known for their soda ash (salt) content and home for a variety of migratory bird species while the latter two are intensively used for a fishery, irrigation, and domestic water consumption currently (Hengsdijk and Jansen, 2006). As a result of such high anthropogenic-induced pressures on land resources and poor management, the study area is presently highly threatened by extensive land degradation, lake water retreat and pollution, and drought and food insecurity (Meshesha et al., 2012; Bekele et al., 2018b).

The population of the study area has increased with an annual average growth rate of about 3\% over the last three decades (Bekele et al., 2018b). The average number of a family is about seven in a rural area. According to data from CSA (CSA, 1994, 2007), the total population of three districts in CRV namely: Arsi Negele, Adami-Tulu-Jido Kombolcha, and Dugda had increased by about 86\% in 2016 from its figure in 1994. About $85 \%$ of the population is still known to live in a rural area (CSA, 2007). 
For the vast majority (85\%) of the population in the region, smallholder mixed rainfed agricultural production is the main economic activity (Melka et al., 2015). There are also a few portions of the rural community who are still engaged in the agropastoral livelihood system. Despite significant attempts made to promote irrigated agriculture over the last two decades in the area, agricultural productivity is still subsistent due to erratic rainfall, recurrent drought, and limited technological applications. Due to this, the majority of the rural population is food insecure and still dependent on external relief aid programs (Bekele et al., 2018b).

\section{Data used and sources}

Long-term meteorological data (30-36 years) and socioeconomic data are the two main data sources used in this study. According to Maharjan and Joshi (2013), temperature and precipitation are widely used to assess climate change and its subsequent impacts. Hence, for climate variability and change analysis, long-term historical temperature and rainfall data were mainly used in this study. Data was specifically obtained from four selected Gaging Stations in CRV namely Meki, Ziway, Bulbula, and Arsi Negele (Table) which are monitored by Ethiopian National Meteorological Agency (NMA). All the stations are found along the rift-floor of the CRV and selected based on proximity to study Districts which were vulnerable to climate change and land use change in recent decades. The 1981-2017 database period was selected to make it match with the period for which land use/cover change was analyzed in previous work by the authors (Bekele et al., 2018a). Data for rural farmers' perception towards climate variability and its effect on their historical land use change was generated through formal households' interview and discussion with focus group and key informants - detail as explained in Bekele et al. (2018b). Accordingly, about 297 survey households were randomly selected and interviewed from two study districts namely Arsi Negele and Adami Tulu-Jido Kombolcha.

Table 1. Data sources and period for rainfall and temperature

\begin{tabular}{c|c|c|c|cc}
\hline \multirow{2}{*}{ Station } & \multirow{2}{*}{ Latitude } & \multirow{2}{*}{ Longitude } & \multirow{2}{*}{$\begin{array}{c}\text { Elevation } \\
\text { (m.a.s.l.) }\end{array}$} & \multicolumn{2}{|c}{ Database period } \\
\cline { 5 - 6 } & & & 1800 & $1981-2016$ & $1988-2017$ \\
\hline Arsi Negele & $7^{\circ} 21^{\prime}$ & $38^{\circ} 39^{\prime}$ & 1700 & $1981-2016$ & NA \\
Bulbula & $7^{\circ} 43^{\prime}$ & $38^{\circ} 43^{\prime}$ & 1700 & $1981-2016$ & NA \\
Meki & $8^{\circ} 09^{\prime}$ & $38^{\circ} 49^{\prime}$ & 1400 & $1981-2016$ & $1981-2017$ \\
Ziway & $7^{\circ} 56^{\prime}$ & $38^{\circ} 43^{\prime}$ & 1640 & 1980 .
\end{tabular}

m.a.s.l. $=$ meter above sea level, NA $=$ data not available (Source: NMA)

\section{Data processing and analysis}

Analysis of mean, standard deviation, coefficient of variation, precipitation concentration index, and standardized precipitation index

The daily time series rainfall and temperature data from each station and for the respective year were checked for homogeneity, outliers, discontinuities, and errors during analysis. Suspected outlier data were cross-checked with data from neighboring stations for typographical errors and corrected when found. Missing data value was filled by using data from a neighboring station. The inter-seasonal/annual trend of 
rainfall and temperature was examined for the study period and each station by processing data using the climatic analysis software, INSTAT version 3.36 following the guideline given by Stern et al. (2006). Mean values, standard deviation (SD), a coefficient of variance (CV), Precipitation Concentration Index (PCI), and standardized precipitation index (SPI) were employed for the analysis. The formula in Equation 1 was used to calculate the SD for rainfall and temperature variability. Rainfall variability is also statistically described by using CV and PCI (Bewket and Conway, 2007). The $\mathrm{CV}$ is calculated as the ratio of the SD to the mean in a given period (Eq. 2), and the PCI values were calculated using Equation 3 as given by Oliver (1980). SPI, also known as Standardized Rainfall Anomaly (SRA), is simply the difference of precipitation from the mean for a specified period divided by SD, where the mean and $S D$ are determined from recorded data (McKee et al., 1993). The SPI values of the rainy season were calculated using the formula given in Equation 4 as in Agnew and Chappell (1999) and Bewket and Conway (2007).

$$
\begin{gathered}
\mathrm{SD}=\sqrt{\left[\sum_{\mathrm{i}=1}^{\mathrm{n}} \frac{\left(\mathrm{x}_{\mathrm{i}}-\mathrm{x}\right)^{2}}{\mathrm{n}}\right]} \\
\mathrm{CV}=\frac{\mathrm{SD}}{\mathrm{X}} * 100 \\
\mathrm{PCI}=\left[\frac{\sum \mathrm{P}_{\mathrm{i}}{ }^{2}}{\left(\sum \mathrm{p}_{i}\right)^{2}}\right]=100 \\
\mathrm{SPI}=\frac{\mathrm{P}_{\mathrm{z}}-\mathrm{P}_{\mathrm{m}}}{\mathrm{SD}}
\end{gathered}
$$

where, $\mathrm{SD}=$ standard deviation, $\mathrm{CV}=$ coefficient of variation, $\mathrm{x}_{\mathrm{i}}=$ individual temperature/rainfall observation, $\mathrm{X}=$ mean rainfall/temperature, $\mathrm{n}=$ number of years considered, PCI $=$ Precipitation Concentration Index, $\mathrm{P}_{\mathrm{i}}=$ the rainfall amount of the $\mathrm{i}^{\text {th }}$ month, SPI $=$ standardized precipitation index, $\mathrm{P}_{\mathrm{t}}=$ annual rainfall in year $\mathrm{t}, \mathrm{P}_{\mathrm{m}}=$ long term mean annual rainfall over a period of observation.

\section{Analysis of onset and cessation of rain, probability of dry spells, and length of growing} season

Previous studies in dryland areas of Africa, including Ethiopia, defined the 'onset of rain' (a successful planting date) as the first occasion after March $1^{\text {st }}$ when the rainfall accumulates for three consecutive days and rainfall is at least $20 \mathrm{~mm}$ and no dry spell of more than ten days in the next 30 days (Sivakumar, 1988; Simane and Struik, 1993; Tesfaye and Walker, 2004). Studies elsewhere described a 'rainy day' as a day receiving rainfall amount of $>=0.85 \mathrm{~mm}$ (Barron et al., 2003; Stern et al., 2006), whereas in this study the value given by Ethiopian National Meteorological Agency (NMA, 2001) (i.e., $>=1 \mathrm{~mm}$ ) was used as a reference for rainfall start which was also used by Seleshi and Zanke (2004). A first-order Markov Chain Model was applied by using INSTAT version 3.36 to analyze the onset of wet and dry spells as described by Stern et al. (2006). This model assumes that the probability of rainfall on a given day depends on whether rainfall did or did not occur on the previous day (Biazin and Sterk, 2013). To get an overview of drought at the study area for the whole year, probabilities of the maximum dry spell lengths over the next 30 days from planting was calculated 
(Tesfaye and Walker, 2004). For this study, a 'dry day' is a day receiving less than $1 \mathrm{~mm}$ of rain and a 'dry spell' is any consecutive number of days defined as 'dry'. The end of the rainy season or cessation was determined by using the water balance dialogue in the INSTAT climatic guide (Stern et al., 2006) and defined as a day after 'first September' when the soil water drops to $10 \mathrm{~mm} \mathrm{~m}^{-2}$. Consequently, the length of the growing season is simply the difference between the rainfall onset date and cessation date (Sivakumar, 1988; Tesfaye and Walker, 2004; Stern et al., 2006). Frequency (F) of dry spells was computed using Equation 5 below as in Sivakumar (1992).

$$
\mathrm{F}(\mathrm{D}<\mathrm{x})=\frac{\mathrm{N}\left(\mathrm{D}_{\mathrm{i}}\right)}{\mathrm{M}} \times 100
$$

where, $\mathrm{N}\left(\mathrm{D}_{\mathrm{i}}\right)$ is the number of years a dry spell of length $<\mathrm{x}$ started in a prescribed 10-day period $\mathrm{i}$, and $\mathrm{M}$ is the total data period (year).

\section{Analysis of effect of climate change vulnerability on land use change}

Studies show that drought vulnerability is much affected not only by climatological events but also by land use type and social contexts. For instance, Biazin and Sterk (2013) analyzed drought vulnerability based on locally perceived criteria of drought and found that the pastoral way of life was more vulnerable to severe drought than the mixed farming (livestock and crop combined) system. Based on these previous vulnerability findings, past historical land use type and future preferences of farmers who are currently engaged in two different land use system (agropastoralist versus mixed farming) were assessed by using a semi-structured questionnaire. The detail about household socioeconomic survey is explained in Bekele et al. (2018b). Accordingly, the study analyzed the change in land use of farmers during the study period, the main reason for changing, and their future preferences (either to continue as agropastoralist, mixed-farmer or other). Additional evidence for land use history was also collected from key informants and experts who were working in the study area for a long period. Finally, simple descriptive statistics were used to evaluate such climate change-induced farmers' historical land use change.

\section{Results}

\section{Rainfall variability and change}

\section{Seasonal and annual rainfall characteristics}

Rainfall of the study area showed both temporal and spatial variability over the study period. Table and Table summarizes the long-term statistics of spatial and seasonal rainfall for four selected sites in CRV while Figure illustrates a time series of bar graph that shows inter-seasonal and inter-annual total rainfall variability. The average precipitation of the driest month $(19.2 \mathrm{~mm})$ and wettest month $(106.1 \mathrm{~mm})$ was observed for November and August respectively. Mean annual total rainfall was below average for about $44 \%$ of the study years. The mean annual total rainfall is lowest $(708 \mathrm{~mm})$ at Bulbula and highest (769 $\mathrm{mm})$ at Arsi Negele. The CV for rainfall is higher at Arsi Negele (43\%) and lower at Ziway $(20 \%)$. On the other hand, monthly rainfall distribution is less concentrated $(\mathrm{PCI}=9)$ at Bulbula and more concentrated $(\mathrm{PCI}=14)$ at Meki. 
Table 2. Spatial rainfall characteristics at four stations in $C R V$

\begin{tabular}{c|c|c|c|c}
\hline Station & Mean & SD & CV (\%) & PCI \\
\hline Arsi Negele & 769.52 & 328.12 & 42.64 & 10.58 \\
Bulbula & 708.33 & 254.76 & 35.97 & 8.66 \\
Meki & 744.19 & 164.16 & 22.06 & 13.59 \\
Ziway & 737.94 & 144.98 & 19.65 & 12.72 \\
Study site & 739.99 & 140.01 & 18.92 & 11.39 \\
\hline
\end{tabular}

$\mathrm{SD}=$ standard deviation, $\mathrm{CV}=$ coefficient of variation, $\mathrm{PCI}=$ Precipitation Concentration Index

Table 3. Seasonal rainfall statistics at four sites in $C R V$

\begin{tabular}{|c|c|c|c|c|c|c|c|c|c|}
\hline \multirow{2}{*}{ Station name } & \multirow{2}{*}{ Season } & \multirow{2}{*}{ Minimum } & \multicolumn{3}{|c|}{$\%$ tile } & \multirow{2}{*}{ Maximum } & \multirow{2}{*}{ Mean } & \multirow{2}{*}{ SD } & \multirow{2}{*}{ CV (\%) } \\
\hline & & & 25 & 50 & 75 & & & & \\
\hline \multirow{3}{*}{ Arsi Negele } & FMAM & 26.90 & 142.70 & 274.20 & 359.40 & 594.40 & 272.04 & 149.07 & 54.80 \\
\hline & JJAS & 70.40 & 235.60 & 354.50 & 487.85 & 1001.00 & 392.04 & 207.83 & 53.01 \\
\hline & ONDJ & 0.00 & 43.10 & 97.50 & 160.10 & 287.25 & 105.44 & 75.32 & 71.43 \\
\hline \multirow{3}{*}{ Bulbula } & FMAM & 64.20 & 173.10 & 248.60 & 321.90 & 635.45 & 264.19 & 119.15 & 45.10 \\
\hline & JJAS & 99.40 & 156.95 & 234.60 & 290.80 & 664.25 & 253.49 & 120.03 & 47.35 \\
\hline & ONDJ & 0.00 & 102.75 & 181.00 & 240.80 & 604.65 & 190.65 & 116.59 & 61.15 \\
\hline \multirow{3}{*}{ Meki } & FMAM & 71.20 & 152.70 & 207.50 & 295.40 & 517.50 & 234.12 & 106.30 & 45.41 \\
\hline & JJAS & 110.95 & 383.00 & 446.70 & 527.20 & 855.10 & 460.68 & 127.87 & 27.76 \\
\hline & ONDJ & 0.00 & 11.30 & 43.20 & 85.30 & 164.30 & 49.39 & 45.19 & 91.48 \\
\hline \multirow{3}{*}{ Ziway } & FMAM & 75.10 & 142.20 & 247.30 & 302.80 & 413.50 & 236.42 & 101.72 & 43.02 \\
\hline & JJAS & 182.50 & 391.40 & 441.60 & 489.10 & 660.70 & 437.36 & 89.80 & 20.53 \\
\hline & ONDJ & 0.00 & 8.50 & 34.80 & 102.00 & 289.80 & 64.16 & 70.74 & 110.25 \\
\hline \multirow{3}{*}{ Study site } & FMAM & 59.35 & 152.68 & 244.40 & 319.88 & 540.21 & 251.69 & 117.72 & 46.77 \\
\hline & JJAS & 115.81 & 291.74 & 369.35 & 448.74 & 795.26 & 385.89 & 133.69 & 34.65 \\
\hline & ONDJ & 0.00 & 41.41 & 89.13 & 147.05 & 336.50 & 102.41 & 75.90 & 74.12 \\
\hline
\end{tabular}

FMAM = February-May, JJAS = June-September, ONDJ = October-January, SD = standard deviation, $\mathrm{CV}=$ coefficient of variation

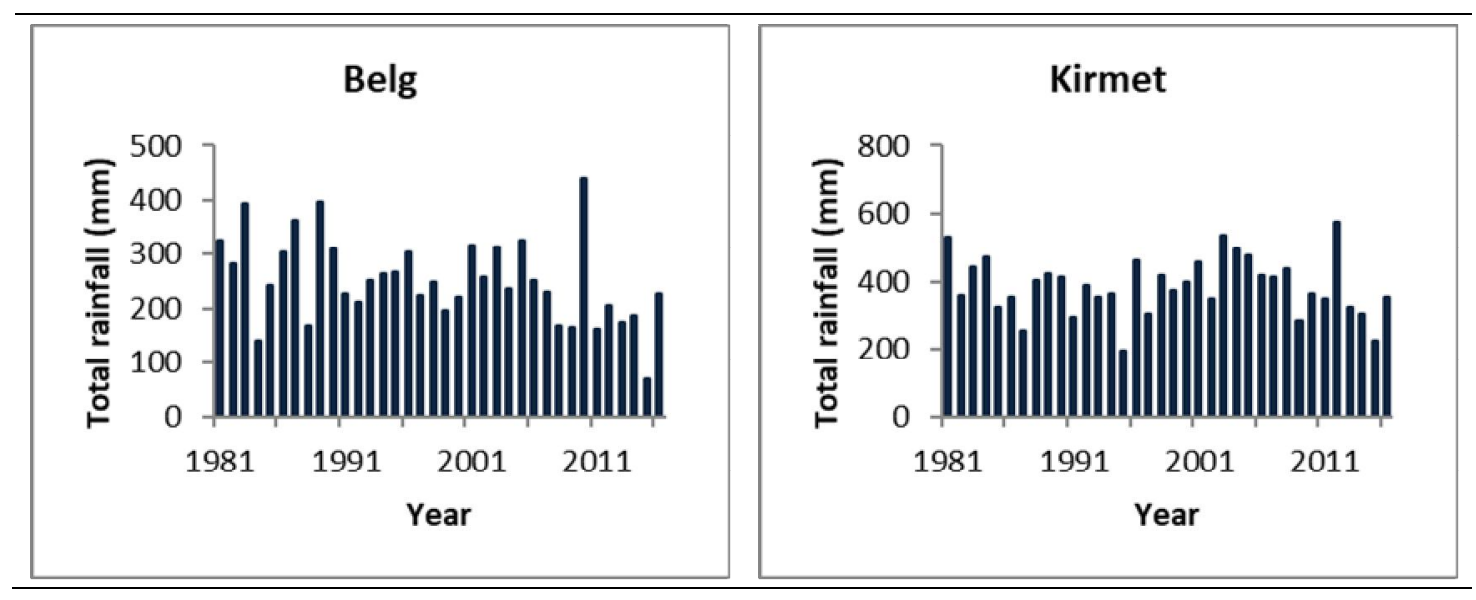

Figure 3. Long-term seasonal total rainfall at $C R V$ 
Rainfall variability along the sites is also observed for both rainy seasons (Table). The overall mean seasonal rainfall ranged from $252 \mathrm{~mm}$ in Belg season (FMAM) to $386 \mathrm{~mm}$ in Kirmet season (JJAS). The coefficient of rainfall variation is higher for Belg season (47\%) than for Kirmet season (35\%). The long-term Belg season minimum rainfall ranged from $27 \mathrm{~mm}$ at Arsi Negele to $75 \mathrm{~mm}$ at Ziway, while the long-term maximum rainfall of the same season ranged from $413 \mathrm{~mm}$ at Ziway to $635 \mathrm{~mm}$ at Bulbula. Mean rainfall of the Belg season was lowest $(234 \mathrm{~mm})$ at Meki and highest $(272 \mathrm{~mm})$ at Arsi Negele. During this season, rainfall is more variable $(\mathrm{CV}=55 \%)$ at Arsi Negele and less variable $(\mathrm{CV}=43 \%)$ at Ziway. On the other hand, the minimum rainfall of the Kirmet season ranged from $70 \mathrm{~mm}$ at Arsi Negele to $182 \mathrm{~mm}$ at Ziway, while the maximum rainfall of the same season ranged from its $661 \mathrm{~mm}$ at Ziway to $1001 \mathrm{~mm}$ at Arsi Negele. The lowest $(253 \mathrm{~mm})$ and highest $(461 \mathrm{~mm})$ mean Kirmet rainfall was recorded for Bulbula and Meki sites respectively. Kirmet season rainfall is more variable $(\mathrm{CV}=53 \%)$ at Arsi Negele and less variable $(\mathrm{CV}=20 \%)$ at Ziway.

\section{Standardized Precipitation Index (SPI)}

The Standardized Precipitation Index (SPI) (Figure) shows an overall picture of average (normal), above average (wet) and below average (dry) years, while Table gives the classification of SPI based on McKee et al. (1993). SPI values ranged from (-)2.34 to $(+) 2.42$ for Belg season and (-)2.23 to $(+) 2.21$ for Kirmet season. As can be seen from Figure, both seasons experienced dry and wet years over the last 36 years.

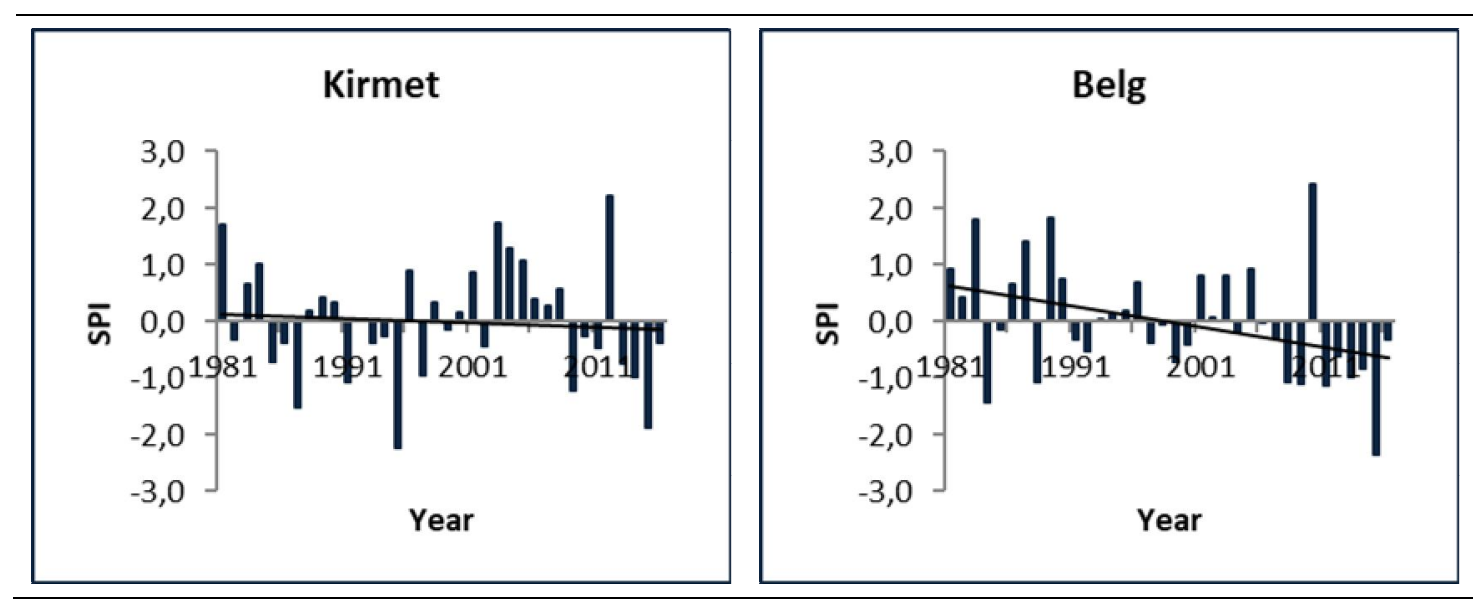

Figure 4. Standardized Precipitation Index (SPI) of the growing season in CRV

For instance, out of the 36 database years considered, rainfall was below average (dry years) during 20 years $(56 \%)$ of Belg season and 18 years $(50 \%)$ of Kirmet season. On the other hand, the linear trend line in Figure indicates that the total annual rainfall showed a general decreasing trend since 1981 during both seasons. According to the SPI classification given by McKee et al. (1993), rainfall of about $44 \%$ and $50 \%$ of the study years fall in the category of no drought/normal for Belg and Kirmet seasons respectively (Table). For the Belg season, the 'extreme drought' year was 2015, whereas for Kirmet season the 'severe drought' and 'extreme drought' years were 1987 and 2015, and 1995, respectively. 
Table 4. Drought evaluation in CRV based on McKee et al. (1993)

\begin{tabular}{|c|c|c|c|c|}
\hline Season & Drought class & Drought/normal years & Frequency & $\begin{array}{c}\begin{array}{c}\text { Percentage of } \\
\text { frequency }\end{array} \\
\end{array}$ \\
\hline \multirow{6}{*}{ Belg } & Extreme drought & 2015 & 1 & 2.8 \\
\hline & Severe drought & - & 0 & 0 \\
\hline & Moderate drought & 1984, 1988, 2008-2009, 2011 & 5 & 13.9 \\
\hline & Mild drought & $\begin{array}{c}1985,1991-1992,1997-2000,2004 \\
2006-2007,2012-2014,2016\end{array}$ & 14 & 38.9 \\
\hline & No drought & $\begin{array}{l}1981-1983,1986-1987,1989-1990 \\
1993-1996,2001-2003,2005,2010\end{array}$ & 16 & 44.4 \\
\hline & Total & & 36 & 100 \\
\hline \multirow{6}{*}{ Kirmet } & Extreme drought & 1995 & 1 & 2.8 \\
\hline & Severe drought & 1987,2015 & 2 & 5.6 \\
\hline & Moderate drought & 1991, 2009 & 2 & 5.6 \\
\hline & Mild drought & $\begin{array}{l}\text { 1982, 1985-1986, 1993-1994, 1997, } \\
1999,2002,2010-2011,2013-2014, \\
2016\end{array}$ & 13 & 36.0 \\
\hline & No drought & $\begin{array}{c}\text { 1981, 1983-1984, 1988-1990, 1992, } \\
\text { 1996, 1998, 2000-2001, 2003-2008, } \\
2012\end{array}$ & 18 & 50.0 \\
\hline & Total & & 36 & 100 \\
\hline
\end{tabular}

\section{Rainfall onset, cessation, and length of growing season}

The onset (start) and cessation (end) date of rainfall for the main rainy season, averaged for the study site is shown in Figure. The average rainfall onset date of the study area is 25 June. Out of the 36 database years considered, for 15 years (42\%), rainfall started later than the average onset date (June 25). On the other hand, the average rainfall cessation date in CRV is 17 September. For 20 years (56\%), out of the 36 years, rainfall stopped earlier than the average cessation date (September 17). The average length of the crop growing season (i.e., the difference between cessation date and onset date) is as shown in Figure. The average growing season in the study area is about three months (84 days), and the median value is 85 days. 1985, 1987, and 1995 were years with a growing season of less than 60 days, whereas 1982, 1988, 1996, 1998, 1999, 2000, and 2012 were years with more than 100 days of growing season.

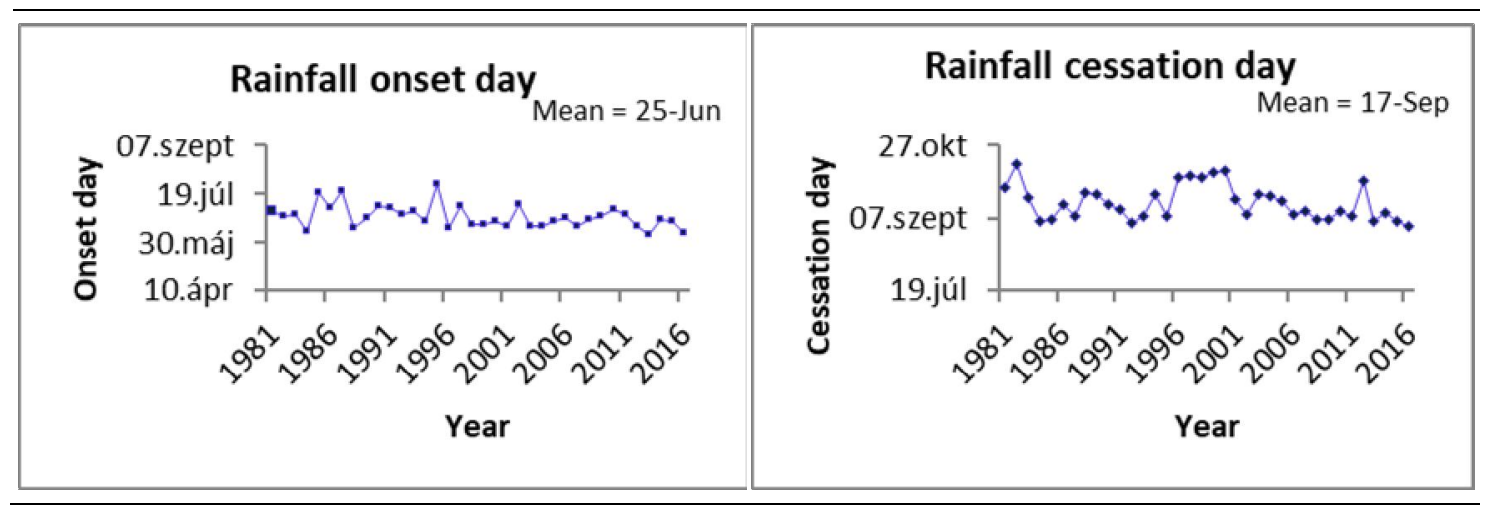

Figure 5. Rainfall onset and cessation day variability in $C R V$ 


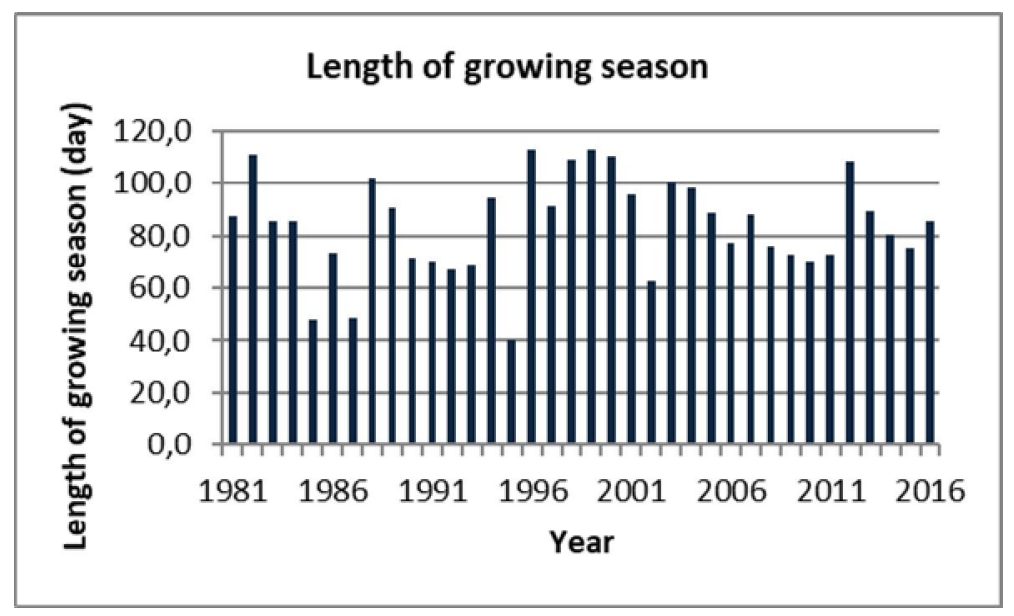

Figure 6. Length of the growing season in CRV

Number of rainy days and probability of dry spells

Figure depicts the trend of rainy days (days with rainfall $>=1 \mathrm{~mm}$ ) and dry spells (days with rainfall $<1 \mathrm{~mm}$ ) for Belg and Kirmet seasons and respective study years. The average number of rainy days in the study area is 23 and 38, while the average number of dry spells is 97 and 84 for Belg and Kirmet seasons respectively. As presented in Figure, the number of rainy days showed a general decreasing trend, whereas the number of dry spells showed a generally increasing trend since 1981 for both Belg and Kirmet seasons.

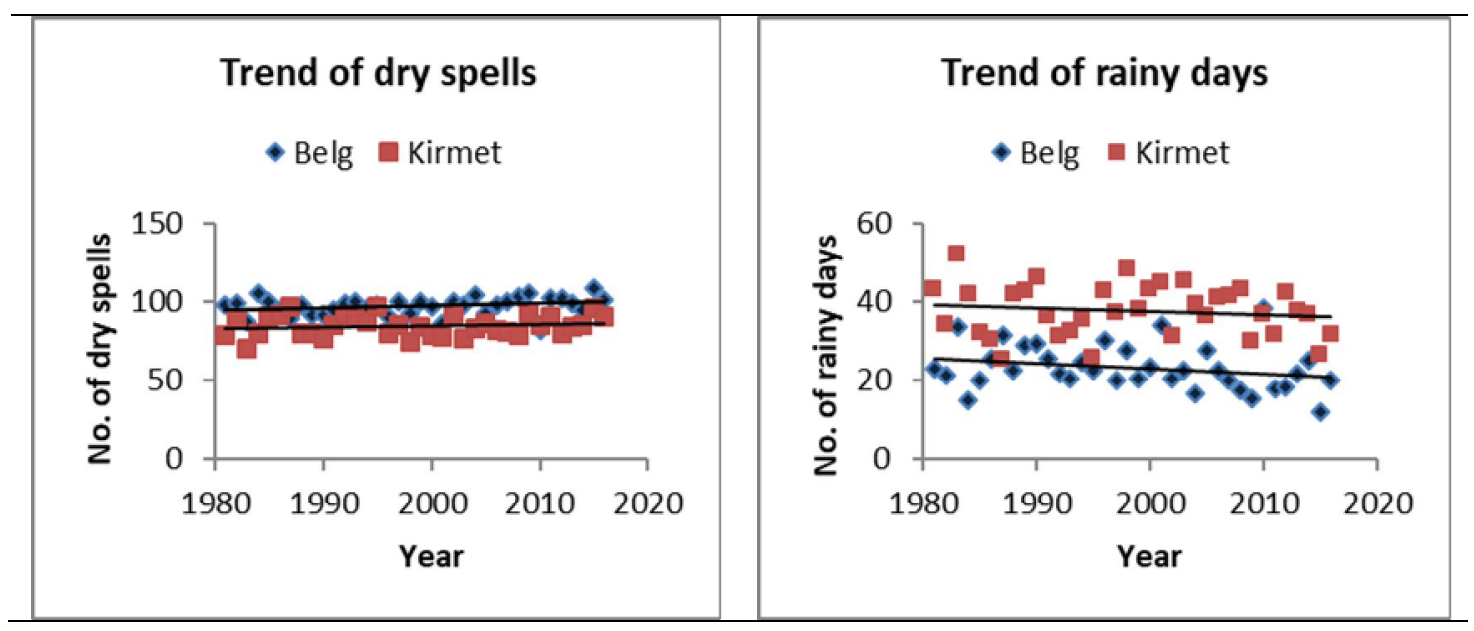

Figure 7. Trend of number of rainy days and dry spells in $C R V$

For example, for Belg season, the average number of rainy days was declined from 25 during 1981-1990 to 20 during 2007-2016 (18\% decline), whereas for the same period, average number of dry spells was increased from 95 to 99. Similarly, for Kirmet season, during the same period, the average number of rainy days was declined from 39 to 36 ( $8 \%$ decline), whereas the average number of dry spells was increased from 83 to 86. On the other hand, the probability of dry spells was found to be higher during Belg season than during Kirmet season of the study years (Figure). 


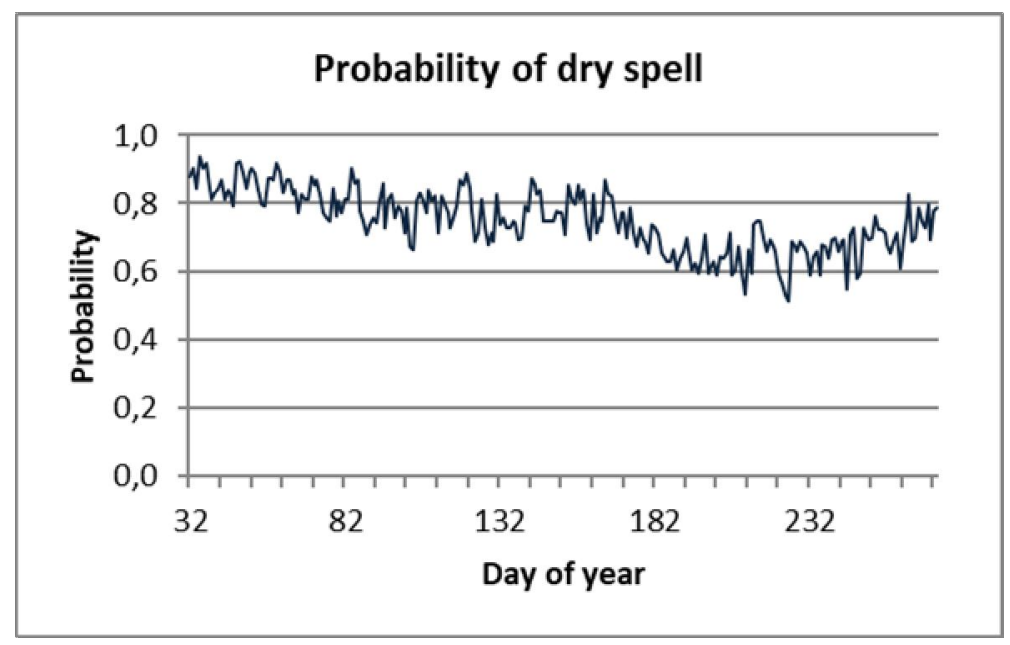

Figure 8. Trend of the probability of dry spells in $C R V$

\section{Temperature variability and change}

Results indicated that the temperature of the study area has shown minor inter-annual and inter-station variability over the study periods (Table and Figure). The average minimum temperature of the coldest month $\left(10.7^{\circ} \mathrm{C}\right)$ and the average maximum temperature of the hottest month $\left(28.8^{\circ} \mathrm{C}\right)$ was observed for December and March respectively.

Table 5. Temperature characteristics at four stations in CRV

\begin{tabular}{c|ccc|ccc}
\hline \multirow{2}{*}{ Station } & \multicolumn{3}{|c|}{ Minimum temperature } & \multicolumn{3}{c}{ Maximum temperature } \\
\cline { 2 - 6 } & Mean & SD & CV & Mean & SD & CV \\
\hline Arsi Negele & 12.20 & 2.22 & 18.19 & 26.57 & 0.88 & 3.32 \\
Bulbula & ND & ND & ND & ND & ND & ND \\
Meki & ND & ND & ND & ND & ND & ND \\
Ziway & 14.14 & 0.89 & 6.28 & 27.36 & 0.97 & 3.55 \\
Study site & 13.24 & 1.26 & 9.51 & 27.12 & 0.55 & 2.03 \\
\hline
\end{tabular}

$\mathrm{SD}=$ standard deviation, $\mathrm{CV}=$ coefficient of variation, $\mathrm{ND}=$ no data available

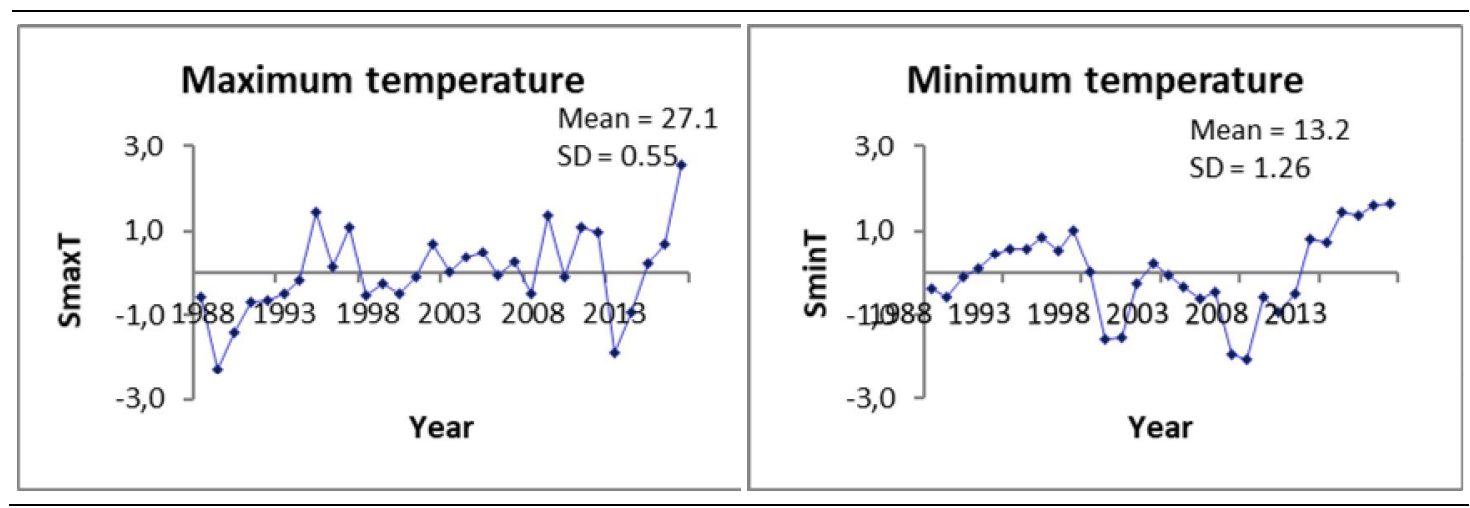

Figure 9. Variability in minimum and maximum temperature in $C R V$ : SminT $=$ standardized minimum temperature, SmaxT $=$ standardized maximum temperature 
Both minimum and maximum temperature values are higher at Ziway than at Arsi Negele. The minimum temperature ranged from its lowest value $\left(10.6^{\circ} \mathrm{C}\right)$ in 2008 to its highest value $\left(15.3^{\circ} \mathrm{C}\right)$ in 2017 , while the maximum temperature ranged from its lowest value $\left(25.9^{\circ} \mathrm{C}\right)$ in 1989 to its highest value $\left(28.5^{\circ} \mathrm{C}\right)$ in 2017 . The minimum temperature had risen above the average value for 15 years $(50 \%)$ out of the 30 years considered. Similarly, the maximum temperature was above average value for 16 years $(53 \%)$ of the data years. On the other hand, both minimum and maximum temperatures showed a relatively continuous increment after 2013.

\section{Effect of climate variability on farmers' land use change}

Table indicates how farmers of the study area have shifted/wish to change their land use system through time in order to adapt to the impacts of climatic and environmental changes over time. About 15 and $35 \%$ of respondents in CRV claimed that they had been pastoralists and agropastoralists respectively before the government change in 1991. However, currently, only $9 \%$ of respondents claimed as being agropastoralists and none of them claimed as fully pastoralist. This indicates about $82 \%$ of farmers who were pastoralists and agropastoralists before three decades had changed their land use to mixed farming and other livelihood activities. On the other hand, as indicated in Table, though the majorities (about 90\%) of the farmers wish to continue as a mixed farmer, none of them wish to continue either as pastoralist or agropastoralist in the future. The rest $10 \%$ of respondents have a wish to shift their livelihood to other activities like offfarm jobs, mini trading, and cattle fattening.

Table 6. Farmers land use change through time $(N=297)$

\begin{tabular}{c|c|c|c}
\hline Type of land use & 30 years before (\%) & Current (\%) & Future wish (Yes, \%) \\
\hline Pastoralist & 15.00 & 0.00 & 0.00 \\
Agropatoralist & 35.50 & 9.10 & 0.00 \\
Mixed farming & 48.50 & 89.00 & 90.10 \\
Other activity & 1.00 & 1.90 & 9.90 \\
\hline
\end{tabular}

The major factors that forced farmers to change their land use system through time are as listed in Table. This change in land use is more observed in communities whose livelihood is more vulnerable to climate change for example, in pastoralists and agropastoralists than in mixed farming communities who are less vulnerable. According to $40 \%$ of respondents, climate variability is the main factor forcing farmers to change their land use system which was followed by the shortage of land due to population growth (30\%), as a second driver of change.

Table 7. Forcing factors offarmers' land use change $(N=297)$

\begin{tabular}{c|c}
\hline Factors & Number of respondents (\%) \\
\hline Climate change & 40 \\
Population growth and shortage of land & 30 \\
Access to market and infrastructure & 15 \\
Institutional and policy changes & 10 \\
Others & 5 \\
\hline
\end{tabular}


Improvements in access to infrastructure and market from time to time and institutional changes following the subsequent government changes in 1974 and 1991 in Ethiopia were also mentioned as substantial factors that contributed for such land use changes in the study area.

\section{Discussion}

Results indicated that rainfall in the study area experienced a high inter-seasonal, inter-annual, and inter-station variability over the last 36 years. For instance, mean annual total rainfall was below average for about $44 \%$ of study years, and the CV of rainfall is about $20 \%$ and above for all seasons and sites. This long-term rainfall variability was also confirmed by the perceived results of the discussion with farmers and experts of the study area (Bekele et al., 2018b). As per the classification given by Hare (1983), total rainfall of CV $<20 \%$ is classified as less variable; CV of $20-30 \%$ as moderately variable, and $\mathrm{CV}$ of $>30 \%$ as highly variable and vulnerable to drought. According to this classification, the overall rainfall in CRV can be categorized in the threshold of 'moderately variable', even though inter-seasonal/station variations are 'highly variable'. On the other hand, the overall PCI value for the study site is about 11 , which indicates that the monthly rainfall distribution of the study area is highly concentrated. According to Oliver (1980), PCI values of less than 10, 11-20, and above 21 are indicators of 'uniform', 'high concentration' and 'very high concentration' monthly distribution of rainfall respectively.

This result is in line with results of previous studies on climate variability in the region (Biazin and Sterk, 2013; Getachew and Tesfaye, 2015; Muluneh et al., 2017) and studies in other parts of Ethiopia (Seleshi and Zanke, 2004; Bewket and Conway, 2007; Cheung et al., 2008; Viste et al., 2013) who reported the prevalence of seasonal rainfall variability and drought in the country over the last decades. Besides climatic fluctuations, there are studies reported the non-stationarity in hydrological variables particularly stream flow and lake level in the Rift Valley Lakes Basin of Ethiopia (Wagesho et al., 2012; Getnet et al., 2014). This affects the available water which, in turn, affects land use. However, other studies reported the absence of significant variation particularly in terms of total annual rainfall as opposed to farmers' usual perception of the presence of total rainfall shortage in the country in recent decades (Rosell, 2011; Kassie et al., 2013; Adimassu et al., 2014). In addition to seasonal variation, Ethiopian precipitation exhibits great spatial variation due to high altitudinal variation over the country (Viste et al., 2013). Coupled with the semi-arid climate and hence moisture-deficient soil of the CRV, variability in rainfall is one of the challenges to the sustainable production of the rain-fed agriculture in the region (Kassie et al., 2013; Gizachew and Shimelis, 2014; Getachew and Tesfaye, 2015), in Ethiopia (Mideksa, 2010), and other semi-arid and dry sub-humid areas in Sub-Saharan Africa (Barron et al., 2003; Viste et al., 2013; Fekadu, 2015; Serdeczny et al., 2017).

In the study area, out of the 36 study years considered, total rainfall was below average (i.e., negative anomalies) for about half of these years. According to the threshold suggested by McKee et al. (1993), SPI values of less than zero are indicators of the presence of drought. SPI and probabilities of drought occurrence are commonly used in evaluating trends of rainfall over a long period (McKee et al., 1993; Agnew and Chappell, 1999; Agnew, 2000; Bewket and Conway, 2007; WMO, 2012; Viste et al., 2013). This is because using SPI has advantages in that other input parameter is not 
needed except precipitation, it can be compared for varied climatic zones and timescales, it gives drought early warning and helps to evaluate the severity of the drought, and it is less complex than the other indices (Agnew, 2000; WMO, 2012). In addition, in areas where data accessibility is limited, Viste et al. (2013) recommend using precipitation-based drought measurements. On the other hand, SPI has weaknesses in that it requires the data to be normally distributed and also its output is affected by the time of the base data period used (Agnew and Chappell, 1999; Agnew, 2000; Ali and Lebel, 2009; WMO, 2012). In addition, there exists a confusion on the definition of the term 'drought' as its impacts can be evaluated in terms of meteorological, climatological, hydrological, agricultural, ecological, and economic aspects (McKee et al., 1993; Agnew, 2000; Viste et al., 2013). However, meteorological drought is the main form of drought, and there is a consensus that drought occurs when rainfall is 'below average' (Agnew and Chappell, 1999).

For a moisture-deficient, semi-arid climate, and a rain-fed dependent agriculture like the one in CRV of Ethiopia, the time of the start of rainfall (onset), the time at which rainfall stop (cessation), and the length of the growing season are very important climatic phenomenon that affects not only the crop cultivation calendar, but also the final yield of production (Seleshi and Zanke, 2004; Segele and Lamb, 2005). Hence, such rainfall analysis has important applications in initiating weather-responsive farming for drought-prone areas like the Sahel and East Africa (Sivakumar, 1988, 1992). As seen from the result, out of the 36 years considered, Kirmet season rainfall in the study area started after the average time of onset for about $42 \%$ of the years, and it ceased ahead of the average time of a stop for about $56 \%$ of the years. This shortens the length of the growing season which directly affects crop productivity due to moisture deficiency in the soil before crop grain filling time. Studies show that there exists a significant relationship between the length of the growing season and the date of onset of rain (Sivakumar, 1988). Early onset of rain is usually followed by a prolonged growing season and vice versa. As pointed in Bekele et al. (2018b), during the discussion, farmers also blamed that late onsets and early cessations of rainfall are the main reasons for the reduction of their crop yield in recent decades.

The average ratio of rainy days to dry spells for the rainy season in the study area is about 1:3. This indicates that the number of dry spells is three times that of rainy days. The number of dry spells showed a generally increasing trend while the number of rainy days has experienced a generally decreasing trend since 1981 for both Belg and Kirmet seasons. On the other hand, the probability of dry spell occurrence was found to be less during Kirmet season than during Belg season. Previous studies also reported the presence of frequent drought in Ethiopia. For example, the years 1972-1975, 19801982, 1984, 1987, 1990-1992, 1999-2000, 2002-2003, and 2008-2011 were the periods of severe drought episodes while the years 1973/74, 1984/85, and 2009 were the nationally widespread and worst drought years in Ethiopia (Jury, 2010; Gebrehiwot et al., 2011; Viste et al., 2013). It is important to match the crop phenology with the dryspell lengths to meet the crop water requirements in the semi-arid and arid regions where moisture is available for a relatively short period during the year (Sivakumar, 1992). Hence, for the choice of a particular crop or variety, such information on the length of dry spells for a given region could be used as a guide.

Similar to rainfall, the temperature (particularly of minimum temperature) has shown an inter-annual variability and a generally increasing trend in recent years. It is evident that an evapotranspiration rate will increase with an increase in temperature which, in 
turn, will contribute to crop productivity decline due to a shortage of available soil moisture in drought-prone areas. Studies in different parts of the country also reported a slight increase in temperature over recent decades (Rosell, 2011; Fazzini et al., 2015; Getachew and Tesfaye, 2015). Local communities and experts relate such an increase in diurnal temperature to massive losses in vegetation coverage of the region due to deforestation over the last decades (Bekele et al., 2018b). An increase in temperature could also be ascribed to global warming effect due to an accumulation of greenhouse gases from intensive agricultural production (Maharjan and Joshi, 2013).

This study finally considered how climate change vulnerability shapes farmers' historical land use. Climate change perception survey results indicated that the variability in climate, particularly the occurrence of recurrent drought, is one of the factors that force drought vulnerable farmers to modify/change their land use system through time. Previous studies also indicate that land use change in CRV is driven by the interaction of frequent drought, socioeconomic and institutional dynamics, and access to market and infrastructures (Biazin and Sterk, 2013; Bekele et al., 2018b). Such climate change-induced change in land use is taken as a means of adaptation strategy to overcome climate change and its impacts (Dale, 1997; Reid et al., 2000; Ahmed et al., 2016). Besides such permanent changes in land use, farmers also use other short-term climate change adaptation mechanisms like changing cropping time, changing crop variety, using off-farm income sources, and selling cattle to overcome critical drought years. Studies show that coupled with climatological changes, the degree of drought vulnerability is also affected by the type of land-uses and social contexts (Biazin and Sterk, 2013). For instance, Biazin and Sterk (2013) in their study found that the pastoral way of life was more vulnerable to severe drought than the mixed farming (livestock and crop combined) system. This indicates that due to drought vulnerability farmers try to shift from a land use system that is more vulnerable to drought (e.g., pastoralist) to a land use system that is less vulnerable (e.g., mixed farming) through time. Another study by Ahmed et al. (2016) in western Africa also confirmed that the increase in agricultural land use in the region was primarily climate-driven.

\section{Conclusions}

Rainfall and temperature data analysis are in common practice to describe climate change and variability. Such analysis not only helps to evaluate the variation exists along spatial and temporal scales but also to see its impacts on the agrarian community. In this study, descriptive statistical tools were used to show long-term inter-seasonal, inter-annual, and inter-site rainfall and temperature variations, and its impacts on land use change in a drought-prone CRV region of Ethiopia. Results indicated that there existed a high inter-seasonal and inter-annual rainfall and temperature variability over the last three decades. For example, total annual rainfall was below average for about $44 \%$ of the 36 years data period. Late-onset and early cessation of rainfall were observed for the majority of the database period. The number of rainy days generally showed a decreasing trend while the number of dry spells showed a generally increasing trend since 1981. Standardized Precipitation Index of the crop growing season also showed negative anomalies (i.e., less than average) for the majority of the study years considered. Extreme and severe drought years were also noted for both rainy seasons (Belg and Kirmet). 
In line with meteorological evidence for drought, vulnerable farmers in the study area well perceived such recurrent drought occurrence over the last three decades and they blamed the change in climate as one of the important forcing factors to change their land use system through time. Majority of the farmers who had been pastoralists/agropastoralists before three decades are currently already changed their land use system to mixed farming, and the rest also have a wish to change in the future. In general, it is evident that climate change plays a significant role in driving historical land use change in drought-prone areas like East Africa. Hence, future policies need to consider strategies that strengthen the adaptation capacity of farmers to overcome drought impact while combating anthropogenic activities that aggravate climate change, for instance, land degradation, in Sub-Saharan countries.

It is believed that for a climate change-prone and rain-fed dependent agriculture, like in East Africa, up-to-date local climatic trend information is quite crucial to practice climate-responsive agricultural management activities like cultivation, water management, health management, and to reduce drought-induced catastrophes. However, this study might have limitations in that we used data from limited meteorological stations and hence future studies better incorporate data from the wider stations in CRV lakes basin. In addition, missing data observed in each station might affect the accuracy of the results to some extent and hence a cross-comparison of the results with reference data elsewhere, for example, World Climate Research Program Global Precipitation Climatology Center (GPCC) might be important. The role of climate change vulnerability in governing land use change also need further detail study. Future studies also need to address the adaptation strategies of farmers to overcome climate change, and the barriers hinder the success of such efforts.

Acknowledgements. The authors are indebted to thank the National Natural Sciences Foundation of China [Grant No. 41571176] and Sino-Africa Cooperation and Exchange Special Program [Fund No. 2018-AF-22) for financial support in conducting this study. We are grateful to thank the Chinese Government Scholarship Council (CSC) for giving the first author a chance to pursue his Ph.D. study in China. Special thanks also go to the Ethiopian National Meteorological Agency (NMA) for providing rainfall and temperature data and all the rural farmers of the three Districts: Dugda, Adami Tulu-Jido Kombolcha, and Arsi Negele, who took part during the field survey. The anonymous referees and editor are thankful for their valuable comments on the initial version of this manuscript.

\section{REFERENCES}

[1] Adimassu, Z., Kessler, A., Stroosnijder, L. (2014): Farmers' strategies to perceived trends of rainfall and crop productivity in the Central Rift Valley of Ethiopia. - Environmental Development 11: 123-140.

[2] Agnew, C. (2000): Using the SPI to identify drought. - Drought Network News (19942001). Paper 1.

[3] Agnew, C., Chappell, A. (1999): Drought in the Sahel. - GeoJournal 48(4): 299-311.

[4] Ahmed, K. F., Wang, G., You, L., Yu, M. (2016): Potential impact of climate and socioeconomic changes on future agricultural land use in West Africa. - Earth System Dynamics 7(1): 151-165.

[5] Ali, A., Lebel, T. (2009): The Sahelian standardized rainfall index revisited. International Journal of Climatology 29(12): 1705-1714. 
[6] Ariti, A. T., van Vliet, J., Verburg, P. H. (2015): Land-use and land-cover changes in the Central Rift Valley of Ethiopia: Assessment of perception and adaptation of stakeholders. - Applied Geography 65: 28-37.

[7] Barron, J., Rockström, J., Gichuki, F., Hatibu, N. (2003): Dry spell analysis and maize yields for two semi-arid locations in east Africa. - Agricultural and Forest Meteorology 117(1-2): 23-37.

[8] Bekele, B., Wu, W., Legesse, A., Temesgen, H., Yirsaw, E. (2018a): Random and Systematic Land Use/Land Cover Transitions in Semi-arid Landscapes of Ethiopian Central Rift Valley Lakes Region (East Africa). - Applied Ecology and Environmental Research 16(4): 3993-4014.

[9] Bekele, B., Wu, W., Legesse, A., Temesgen, H., Yirsaw, E. (2018b): Socioenvironmental impacts of land use/cover change in Ethiopian Central Rift Valley lakes region, East Africa. - Applied Ecology and Environmental Research 16(5): 6607-6632.

[10] Bewket, W., Conway, D. (2007): A note on the temporal and spatial variability of rainfall in the drought-prone Amhara region of Ethiopia. - International Journal of Climatology 27(11): 1467-1477.

[11] Biazin, B., Sterk, G. (2013): Drought vulnerability drives land-use and land cover changes in the Rift Valley dry lands of Ethiopia. - Agr Ecosyst Environ 164: 100-113.

[12] Cheung, W. H., Senay, G. B., Singh, A. (2008): Trends and spatial distribution of annual and seasonal rainfall in Ethiopia. - International Journal of Climatology 28(13): 17231734.

[13] Collier, P., Conway, G., Venables, T. (2008): Climate change and Africa. - Oxford Review of Economic Policy 24(2): 337-353.

[14] Conway, D. (2000): Some aspects of climate variability in the north east Ethiopian Highlands-Wollo and Tigray. - Sinet: Ethiopian Journal of Science 23(2): 139-161.

[15] Conway, D., Mould, C., Bewket, W. (2004): Over one century of rainfall and temperature observations in Addis Ababa, Ethiopia. - International Journal of Climatology: A Journal of the Royal Meteorological Society 24(1): 77-91.

[16] CSA (1994): The 1994 population and housing census results for Oromiya Region. Central Statistical Agency, Addis Ababa, Ethiopia.

[17] CSA (2007): The 2007 population and housing census results for Oromiya Region. Central Statistical Agency, Addis Ababa, Ethiopia.

[18] Dale, V. H. (1997): The relationship between land-use change and climate change. - Ecol App 7(3): 753-769.

[19] Eckstein, D., Künzel, V., Schäfer, L. (2017): Global climate risk index 2018. Germanwatch eV: Bonn, Germany.

[20] Fazzini, M., Bisci, C., Billi, P. (2015): The climate of Ethiopia. - In: Billi, P. (ed.) Landscapes and Landforms of Ethiopia. Springer, Dordrecht, pp 65-87.

[21] Fekadu, K. (2015): Ethiopian seasonal rainfall variability and prediction using canonical correlation analysis (CCA). - Earth Sciences 4(3): 112.

[22] Garedew, E., Sandewall, M., Soderberg, U., Campbell, B. M. (2009): Land-use and landcover dynamics in the central rift valley of Ethiopia. - Environ Manage 44(4): 683-694.

[23] Gebrehiwot, T., van der Veen, A., Maathuis, B. (2011): Spatial and temporal assessment of drought in the Northern highlands of Ethiopia. - Theoretical and Applied Climatology 13(3): 309-321.

[24] Gemeda, D. O., Sima, A. D. (2015): The impacts of climate change on African continent and the way forward. - Journal of Ecology and the Natural environment 7(10): 256-262.

[25] Getachew, H., Tesfaye, K. (2015): Analysis of risks in crop production due to climate change in the Central Rift Valley of Ethiopia. - African Journal of Agricultural Research 10(16): 1913-1922.

[26] Getnet, M., Hengsdijk, H., van Ittersum, M. (2014): Disentangling the impacts of climate change, land use change and irrigation on the Central Rift Valley water system of Ethiopia. - Agricultural Water Management 137: 104-115. 
[27] Gizachew, L., Shimelis, A. (2014): Analysis and mapping of climate change risk and vulnerability in Central Rift Valley of Ethiopia. - African Crop Science Journal 22: 807818.

[28] Hare, F. (1983): Climate and Desertification: a revised analysis. - World Climate Program, report, Geneva, Switzerland.

[29] Hengsdijk, H., Jansen, H. (2006): Agricultural development in the Central Ethiopian Rift valley: A desk-study on water-related issues and knowledge to support a policy dialogue. - Note 375. Plant Research International BV., Wageningen.

[30] IPCC (2007): Climate change 2007: impacts, adaptation, and vulnerability. Contribution of working group II to the fourth assessment report of the intergovernmental panel on climate change. Cambridge University Press, Cambridge.

[31] IPCC (2014): Climate Change 2014 Synthesis Report Summary for Policymakers. Contribution of working group to the fifth assessment report of the intergovernmental panel on climate change. Cambridge University Press, Cambridge.

[32] Jansen, H., Hengsdijk, H., Legesse, D., Ayenew, T., Hellegers, P., Spliethoff, P. (2007): Land and water resources assessment in the Ethiopian Central Rift Valley. - Project: Ecosystems for water, food and economic development in the Ethiopian Central Rift Valley, Alterra-rapport 1587. Wageningen, Alterra.

[33] Jury, M. R. (2010): Ethiopian decadal climate variability. - Theoretical and Applied Climatology 101(1-2): 29-40.

[34] Kassie, B. T., Hengsdijk, H., Rotter, R., Kahiluoto, H., Asseng, S., Van Ittersum, M. (2013): Adapting to climate variability and change: experiences from cereal-based farming in the central rift and Kobo Valleys, Ethiopia. - Environ Manage 52(5): 11151131.

[35] Maharjan, K. L., Joshi, N. P. (2013): Climate change, agriculture and rural livelihoods in developing countries. - Springer, Japan.

[36] McKee, T. B., Doesken, N. J., Kleist, J. (1993): The relationship of drought frequency and duration to time scales. - In: Proceedings of the 8th Conference on Applied Climatology, vol 22. American Meteorological Society Boston, MA, pp 179-183.

[37] Melka, Y., Kassa, H., Ketema, M., Abebaw, D., Schmiedel, U. (2015): The effect of drought risk perception on local people coping decisions in the Central Rift Valley of Ethiopia. - J Dev Agric Econ 7(9): 292-302.

[38] Meshesha, D. T., Tsunekawa, A., Tsubo, M. (2012): Continuing land degradation: causeeffect in Ethiopia's Central Rift Valley. - Land Degrad Dev 23(2): 130-143.

[39] Mideksa, T. K. ( 2010): Economic and distributional impacts of climate change: The case of Ethiopia. - Global Environmental Change 20: 278-286.

[40] Muluneh, A., Bewket, W., Keesstra, S., Stroosnijder, L. (2017): Searching for evidence of changes in extreme rainfall indices in the Central Rift Valley of Ethiopia. - Theoretical and Applied Climatology 128(3-4): 795-809.

[41] NMA (2001): Report submitted to initial national communication of Ethiopia to the United Nations Framework Convention on Climate Change. - National Meteorological Services Agency, Addis Ababa, Ethiopia.

[42] Oliver, J. E. (1980): Monthly precipitation distribution: a comparative index. - The Professional Geographer 32(3): 300-309.

[43] Pedrono, M., Locatelli, B., Ezzine-de-Blas, D., Pesche, D., Morand, S., Binot, A. (2016): Impact of climate change on ecosystem services. - In: Torquebiau, E. (ed.) Climate Change and Agriculture Worldwide. Springer, London pp 251-261.

[44] Ravindranath, N. H., Sathaye, J. A. (2002): Climate Change and Developing Countries. Kluwer Academic Publishers, Dordrecht, The Nitherlands.

[45] Reid, R. S., Kruska, R. L., Muthui, N., Taye, A., Wotton, S., Wilson, C. J., Mulatu, W. (2000): Land-use and land-cover dynamics in response to changes in climatic, biological and socio-political forces: the case of southwestern Ethiopia. - Landscape Ecol 15(4): 339-355. 
[46] Rosell, S. (2011): Regional perspective on rainfall change and variability in the central highlands of Ethiopia, 1978-2007. - Applied Geography 31(1): 329-338.

[47] Segele, Z. T., Lamb, P. J. (2005): Characterization and variability of Kiremt rainy season over Ethiopia. - Meteorology and Atmospheric Physics 89(1-4): 153-180.

[48] Seleshi, Y., Zanke, U. (2004): Recent changes in rainfall and rainy days in Ethiopia. International journal of climatology 24(8): 973-983.

[49] Serdeczny, O., Adams, S., Baarsch, F., Coumou, D., Robinson, A., Hare, W., Schaeffer, M., Perrette, M., Reinhardt, J. (2017): Climate change impacts in Sub-Saharan Africa: from physical changes to their social repercussions. - Regional Environmental Change 17(6): 1585-1600.

[50] Simane, B., Struik, P. (1993): Agroclimatic analysis: a tool for planning sustainable durum wheat (Triticum turgidum var. durum) production in Ethiopia. - Agriculture, Ecosystems \& Environment 47(1): 31-46.

[51] Sivakumar, M. (1988): Predicting rainy season potential from the onset of rains in Southern Sahelian and Sudanian climatic zones of West Africa. - Agricultural and Forest Meteorology 42(4): 295-305.

[52] Sivakumar, M. (1992): Empirical analysis of dry spells for agricultural applications in West Africa. - Journal of Climate 5(5): 532-539.

[53] Stern, R., Rijks, D., Dale, I., Knock, J. (2006): INSTAT climatic guide. - University of Reading.

[54] Temesgen, H., Nyssen, J., Zenebe, A., Haregeweyn, N., Kindu, M., Lemenih, M., Haile, M. (2013): Ecological succession and land use changes in a lake retreat area (Main Ethiopian Rift Valley). - J Arid Environ 91: 53-60.

[55] Tesfaye, K., Walker, S. (2004): Matching of crop and environment for optimal water use: the case of Ethiopia. - Physics and Chemistry of the Earth, Parts A/B/C 29(15-18): 10611067.

[56] Torquebiau, E., Tissier, J., Grosclaude, J.-Y. (2016): How climate change reshuffles the cards for agriculture. - In: Torquebiau, E. (ed.) Climate Change and Agriculture Worldwide. Springer, pp 1-16.

[57] UNFCCC (2007): Climate change: Impacts, vulnerabilities and adaptation in developing countries. - United Nations Framework Convention on Climate Change.

[58] UNFCCC (2018): UN Climate Change Annual Report 2017. - United Nations Framework Convention on Climate Change. Bonn.

[59] Viste, E., Korecha, D., Sorteberg, A. (2013): Recent drought and precipitation tendencies in Ethiopia. - Theoretical and Applied Climatology 112(3-4): 535-551.

[60] Wagesho, N., Goel, N., Jain, M. (2012): Investigation of non-stationarity in hydroclimatic variables at Rift Valley lakes basin of Ethiopia. - Journal of Hydrology 444: 113-133.

[61] WMO (2012): Standardized precipitation index user guide. - United Nations Geneva, Switzerland. 